\title{
Synthesis and Characterization of Bioactive Cadmium (II) Complexes Derived from 4-Benzyloxybenzoylhydrazine with Different Aromatic Aldehydes
}

\author{
Rezaul Haque Ansary ${ }^{*}$, Jaber Al Mamun, Md. Belayet Hossain Howlader \\ Department of Chemistry, Rajshahi University, Rajshahi, Bangladesh \\ Email address: \\ ansarychem@gmail.com (R. H. Ansary), jamamunchem@gmail.com(J. Al Mamun), mbhhowlader@yahoo.com (Md. B. H. Howlader) \\ ${ }^{*}$ Corresponding author
}

To cite this article:

Rezaul Haque Ansary, Jaber Al Mamun, Md. Belayet Hossain Howlader. Synthesis and Characterization of Bioactive Cadmium (II)

Complexes Derived from 4-Benzyloxybenzoylhydrazine with Different Aromatic Aldehydes. Science Journal of Chemistry.

Vol. 8, No. 3, 2020, pp. 59-65. doi: 10.11648/j.sjc.20200803.13

Received: May 6, 2020; Accepted: May 28, 2020; Published: June 17, 2020

\begin{abstract}
The reactions of the ligand precursor 4-benzyloxybenzoylhydrazine (2) with cinnamaldehyde, salicylaldehyde, 2,4-dimethoxybenzaldehyde, 4-N,N dimethylaminobenzaldehyde, 4-methoxybenzaldehyde formed the ligands $\mathrm{C}_{6} \mathrm{H}_{5} \mathrm{CH}_{2} \mathrm{OC}_{6} \mathrm{H}_{4} \mathrm{CONHN}=\mathrm{CHR}$, where $\mathrm{R}=\mathrm{C}_{6} \mathrm{H}_{5} \mathrm{CH}=\mathrm{CH}$, (3); $\mathrm{C}_{6} \mathrm{H}_{4}(\mathrm{OH}),(4) ; \mathrm{C}_{6} \mathrm{H}_{3}\left(\mathrm{OCH}_{3}\right)_{2},(5) ; \mathrm{C}_{6} \mathrm{H}_{4} \mathrm{~N}_{(}\left(\mathrm{CH}_{3}\right)_{2},(6) ; \mathrm{C}_{6} \mathrm{H}_{4}\left(\mathrm{OCH}_{3}\right)$, (7), respectively. The ligand precursor 4-benzyloxybenzoylhydrazine (2) was synthesized by the condensation reaction of ethyl-4-benzyloxybenzoate (1) with hydrazine hydrate. Ethyl-4-benzyloxybenzoate (1) was synthesized by the reaction of ethyl-4-hydroxybenzoate and benzyl bromide dissolved in acetone in presence of anhydrous potassium carbonate. By the reactions of the synthesized ligands with cadmium(II) acetate, a series of complexes $\left[\left(\mathrm{C}_{6} \mathrm{H}_{5} \mathrm{CH}_{2} \mathrm{OC}_{6} \mathrm{H}_{4} \mathrm{CONHN}=\mathrm{CHR}\right)_{2} \mathrm{Cd}\right]$ were obtained, where $\mathrm{R}=\mathrm{C}_{6} \mathrm{H}_{5} \mathrm{CH}=\mathrm{CH}$, (8); $\mathrm{C}_{6} \mathrm{H}_{4}(\mathrm{OH})$, (9); $\mathrm{C}_{6} \mathrm{H}_{3}\left(\mathrm{OCH}_{3}\right)_{2}$, (10); $\mathrm{C}_{6} \mathrm{H}_{4} \mathrm{~N}\left(\mathrm{CH}_{3}\right)_{2}$, (11); $\mathrm{C}_{6} \mathrm{H}_{4}\left(\mathrm{OCH}_{3}\right)$, (12). The complexes cannot be obtained via a template method. The compounds have been characterized by elemental analysis, conductivity measurements, UV-visible, FT-IR, ${ }^{1} \mathrm{H}$ NMR spectral studies. The conductivity measurement data revealed that the complexes are non-electrolytic in nature. The UV-visible data of the complexes suggested the tetrahedral geometry of $\mathrm{Cd}(\mathrm{II})$ ion. The antibacterial results of the ligands (3-7) exhibited very low or no activity against pathogenic bacteria viz. gram positive (Bacillus anthracis, Staphylococcus aureus, Bacillus megaterium) and gram negative (Shigella flexneri, Escherichia coli, Shigella shiga), whereas their corresponding complexes (8-12) exhibited activity against the aforementioned bacteria but less than the standard drug, kanamycine. This implies that the activity showed by the complexes is solely responsible for the presence of Cadmium (II) ion.
\end{abstract}

Keywords: Schiff Base, Aroylhydrazone, Spectroscopy, Antibacterial Activity

\section{Introduction}

Hydrazones are an important class of Schiff base ligands which exhibit several applications in pharmaceutical field due to their biological activities including antimicrobial, antifungal, antitumor, antitubercular properties [1-5]. Aroylhydrazones have been widely used as ligands in the preparation of a variety of transition metal complexes [6-11]. The aroylhydrazone moiety may coordinate to the metal through the keto or enol forms [3,12]. The complexing ability of the aroylhydrazone ligand increases through the enol form $[\mathrm{R}-\mathrm{C}(=\mathrm{O}) \mathrm{NH}-\mathrm{N}=\mathrm{C}<\leftrightarrow \mathrm{R}-\mathrm{C}(\mathrm{OH})=\mathrm{N}-\mathrm{N}=\mathrm{C}<] \quad$ as the $\pi$ conjugation of aroyl or aroalkyl group increases. The synthesis and biological studies of cadmium complexes derived from aroylhydrazones through aforementioned keto-enol transformation has not been explored yet. Therefore, the aim of the present study was to synthesize ligands by the reaction of 4-benzyloxybenzoylhydrazine with several aromatic aldehydes and to synthesize $\mathrm{Cd}(\mathrm{II})$ complexes by the reaction of the synthesized ligands and cadmium(II) acetate. Moreover, the antibacterial activity of the ligands and complexes has been evaluated against some pathogenic bacteria. 


\section{Experimental}

\subsection{Materials and Methods}

All the reagents were of AR grade and the solvents were purified by standard methods [3]. The ligand precursor (2) and the ligands (3-7) were synthesized according to a known method [3]. IR spectra were taken as $\mathrm{KBr}$ disc using a Shimadzu FTIR-8101 spectrometer from 4000-250 $\mathrm{cm}^{-1} .{ }^{1} \mathrm{H}$ NMR spectra were obtained in DMF by using JNM-400FT NMR (Bruker Spectrospin) spectrometer. Microanalysis for carbon, hydrogen, and nitrogen were obtained by using Perkin-Elmer $2400 \mathrm{CHN}$ elemental analyzer. Magnetic moments were measured using a magnetic susceptibility balance. Conductivities of the compounds were determined by using CG 857 schott-Grate $\mathrm{GmbH}$ conductivity meter in DMSO with a dip type cell having a platinum electrode. The UV-visible spectra were run on a Shimadzu UV-160 spectrometer in the range of $200-700 \mathrm{~nm}$ in DMF $\left(10^{-4} \mathrm{M}\right.$ solution). Melting points were recorded with an electro-thermal melting point apparatus and the cadmium contents were determined gravimetrically [13].

\subsection{Preparation of Ethyl-4-benzyloxybenzoate (1)}

A mixture of ethyl-4-hydroxybenzoate $(8.30 \mathrm{~g}, 50.00 \mathrm{mmol})$, benzyl bromide $(8.64 \mathrm{~g}, 50.51 \mathrm{mmol})$ and anhydrous potassium carbonate $(12.54 \mathrm{~g}, 90.73 \mathrm{mmol})$ in acetone $(100$ $\mathrm{mL}$ ) was refluxed for 60 hours. Solvent was removed in vacuum line and the solid mass was treated with water (75 $\mathrm{mL})$. The product was extracted with dichloromethane $(4 \times 30 \mathrm{~mL})$ and left for overnight to give a colorless crystal, filtered and washed with pet-ether (to remove any traces of starting materials) and dried in vacuum desiccators over anhydrous $\mathrm{CaCl}_{2}$. The product was free from starting materials (checked by TLC).

\subsection{Preparation of 4-benzyloxybenzoylhydrazine (2)}

A mixture of ethyl-4-benzyloxybenzoate $(5.00 \mathrm{~g}, 19.53$ $\mathrm{mmol})$ and hydrazine hydrate $(2.93 \mathrm{~g}, 58.52 \mathrm{mmol})$ was refluxed in ethanol $(25 \mathrm{~mL})$ for 72 hours. The reaction mixture was cooled to room temperature and a silky white precipitate was formed. The product was filtered off on suction line and washed with excess water (to remove excess hydrazine hydrate) and finally with pet-ether $(40-60 \mathrm{~mL})$. The product was recrystallized from hot ethanol and the purity was checked by TLC.

\subsection{Preparation of Ligands from Corresponding Aldehydes $\left(\mathrm{C}_{6} \mathrm{H}_{5} \mathrm{CH}_{2} \mathrm{OC}_{6} \mathrm{H}_{4} \mathrm{CONHN}=\mathrm{CHR}\right.$, Where $R=C_{6} H_{5} C H=C H,(3) ; C_{6} H_{4}(O H),(4) ; C_{6} H_{3}\left(O_{C H}\right)_{2}$, (5); $\mathrm{C}_{6} \mathrm{H}_{4} \mathrm{~N}\left(\mathrm{CH}_{3}\right)_{2},(6) ; \mathrm{C}_{6} \mathrm{H}_{4}\left(\mathrm{OCH}_{3}\right)$, (7)}

A mixture of 4-benzyloxybenzoylhydrazine $(0.969 \mathrm{~g}$, $4 \mathrm{mmol})$ and cinnamaldehyde $(0.58 \mathrm{~g}, 4 \mathrm{mmol})$ was refluxed in ethanol $(25 \mathrm{~mL})$ for half an hour. The reaction mixture was cooled to room temperature and a white precipitate was obtained. The product was filtered off on a suction line and washed with excess ethanol. It was recrystallized from chloroform and obtained compound (3). The same procedure was applied for the preparation of compounds (4-7) by using 2-hydroxybenzaldehyde, 2,4-dimethoxybenzaldehyde, 4-N, $\mathrm{N}$-dimethylaminobenzaldehyde, 4-methoxy benzaldehyde, respectively.

\subsection{Preparation of Complexes from Corresponding Ligands $\left.\left[\mathrm{C}_{6} \mathrm{H}_{5} \mathrm{CH}_{2} \mathrm{OC}_{6} \mathrm{H}_{4} \mathrm{CONHN}=\mathrm{CHR}\right)_{2} \mathrm{Cd}\right]$ where, $\mathrm{R}=\mathrm{C}_{6} \mathrm{H}_{5} \mathrm{CH}=\mathrm{CH},(8) ; \mathrm{C}_{6} \mathrm{H}_{4}(\mathrm{OH}),(9) ; \mathrm{C}_{6} \mathrm{H}_{3}\left(\mathrm{OCH}_{3}\right)_{2}$, (10); $\mathrm{C}_{6} \mathrm{H}_{4} \mathrm{~N}\left(\mathrm{CH}_{3}\right)_{2},(11) ; \mathrm{C}_{6} \mathrm{H}_{4}\left(\mathrm{OCH}_{3}\right)$, (12)}

\subsubsection{Preparation of bis [N-cinnamalidene(4-benzylo xybenzoyl)hydrazinato/Cd(II), (8)}

To the solution of [N-Cinnamalidene(4-benzyloxybenzoyl) hydrazone], (3) $(0.356 \mathrm{~g}, 1 \mathrm{mmol}$ in $20 \mathrm{~mL}$ ethanol) and cadmium acetate $(0.133 \mathrm{~g}, 0.5 \mathrm{mmol}$ in $20 \mathrm{~mL}$ ethanol) was refluxed for two hours. Pale yellow precipitate was formed. The product was collected by filtration and washed thoroughly with hot ethanol. It was recrystallized from DMSO and pale yellow microcrystalline solid product (8) was obtained.

\subsubsection{Preparation of bis [N-2-hydroxybenzalidene (4-benzyloxy benzoyl)hydrazinato/Cd(II), (9)}

To the solution of [N-2-hydroxy benzalidene (4-benzyloxy benzoyl) hydrazone], (4) $(0.346 \mathrm{~g}, 1 \mathrm{mmol}$ in $20 \mathrm{~mL}$ ethanol) and cadmium acetate $(0.133 \mathrm{~g}, 0.5 \mathrm{mmol}$ in $20 \mathrm{~mL}$ ethanol) was refluxed for three hours. Pale yellow precipitate was formed. The product was collected by filtration and washed thoroughly with hot ethanol. It was recrystallized from DMSO and pale yellow microcrystalline solid product (9) was obtained.

\subsubsection{Preparation of bis $[\mathrm{N}-(2,4-$ dimethoxybenzylidene) (4-benzyloxybenzoyl)hydrazinato/Cd(II), (10)}

To the solution of [N-(2, 4-dimethoxybenzylidine) (4-benzyloxybenzoyl)hydrazone], (5) (0.390g, $1 \mathrm{mmol}$ in 20 $\mathrm{mL}$ ethanol) and cadmium acetate $(0.133 \mathrm{~g}, 0.5 \mathrm{mmol}$ in $20 \mathrm{~mL}$ ethanol) was refluxed for two hours. White precipitate was formed. The product was collected by filtration and washed thoroughly with hot ethanol. It was recrystallized from DMSO and white microcrystalline solid product (10) was obtained.

\subsubsection{Preparation of bis/ $\mathrm{N}-(4-\mathrm{N}, \mathrm{N}$-dimethylamino benzylidene) (4-benzyloxybenzoyl)hydrazinato] Cd(II)(11)}

To the solution of [N-(4-N, N-dimethylaminobenzylidene) (4-benzyloxybenzoyl)hydrazone], (6) $(0.372 \mathrm{~g}, 1 \mathrm{mmol}$ in 20 $\mathrm{mL}$ ethanol) and cadmium acetate $(0.133 \mathrm{~g}, 0.5 \mathrm{mmol}$ in $20 \mathrm{~mL}$ ethanol) was refluxed for three hours. White precipitate was formed. The product was collected by filtration and washed thoroughly with hot ethanol. It was recrystallized from DMSO and white microcrystalline solid product (11) was obtained.

\subsubsection{Preparation of bis[N-(4-methoxybenzylidene) (4-benzyloxybenzoyl)hydrazinato/Cd(II), (12)}

To the solution of [N-(4-methoxybenzylidene) (4-benzyloxybenzoyl)hydrazone], (7) $(0.359 \mathrm{~g}, 1 \mathrm{mmol}$ in 20 $\mathrm{mL}$ ethanol) and cadmium acetate $(0.133 \mathrm{~g}, 0.5 \mathrm{mmol}$ in $20 \mathrm{~mL}$ ethanol) was refluxed for three hours. White precipitate was 
formed. The product was collected by filtration and washed thoroughly with hot ethanol. It was recrystallized from DMSO and white microcrystalline solid product (12) was obtained.
All the reactions performed in this study are shown in Figure 1.
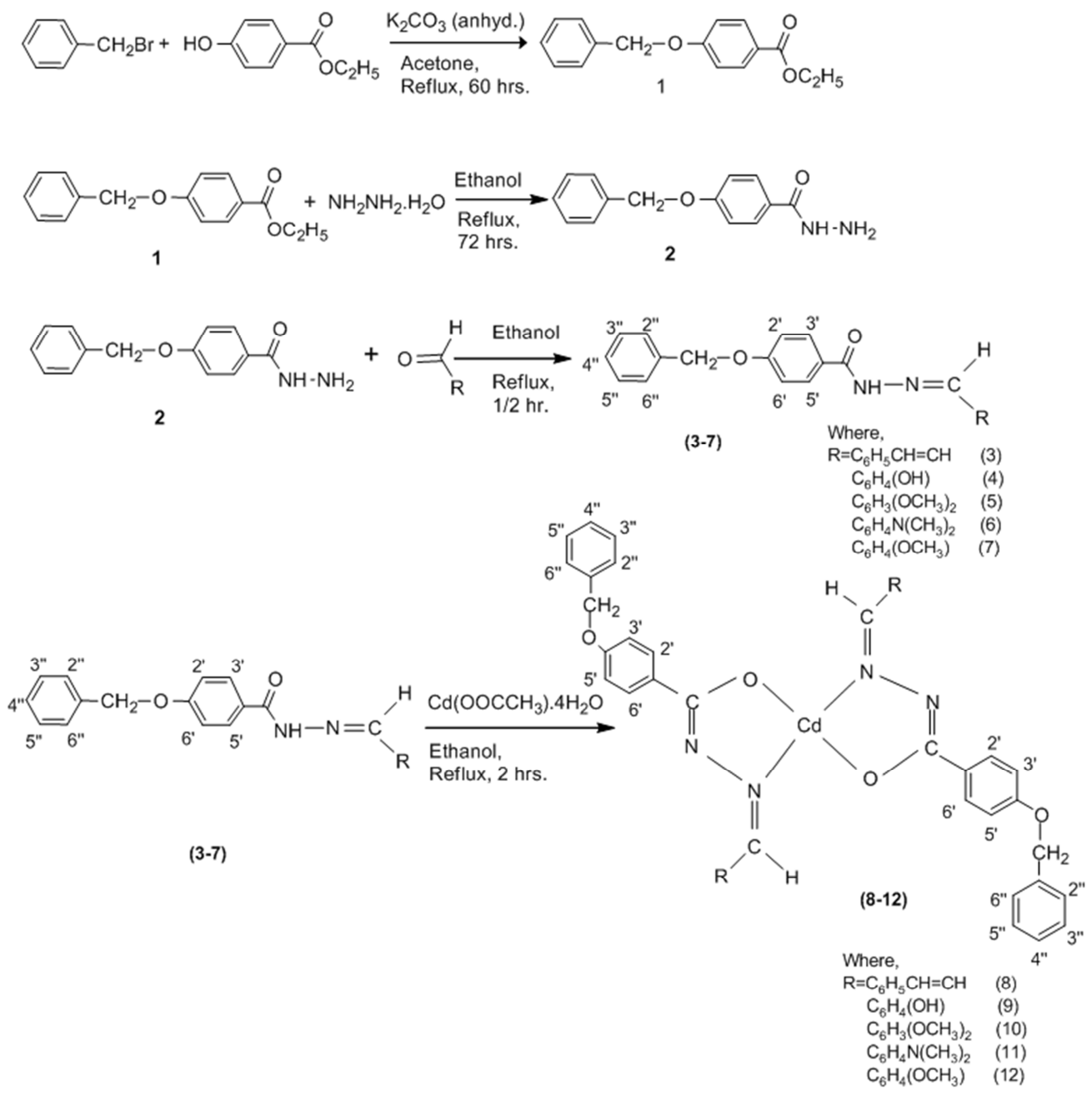

Figure 1. Synthetic scheme of ligands and its Cd(II) complexes.

Table 1. Analytical data, molar conductance and magnetic moments of the compounds (3-12).

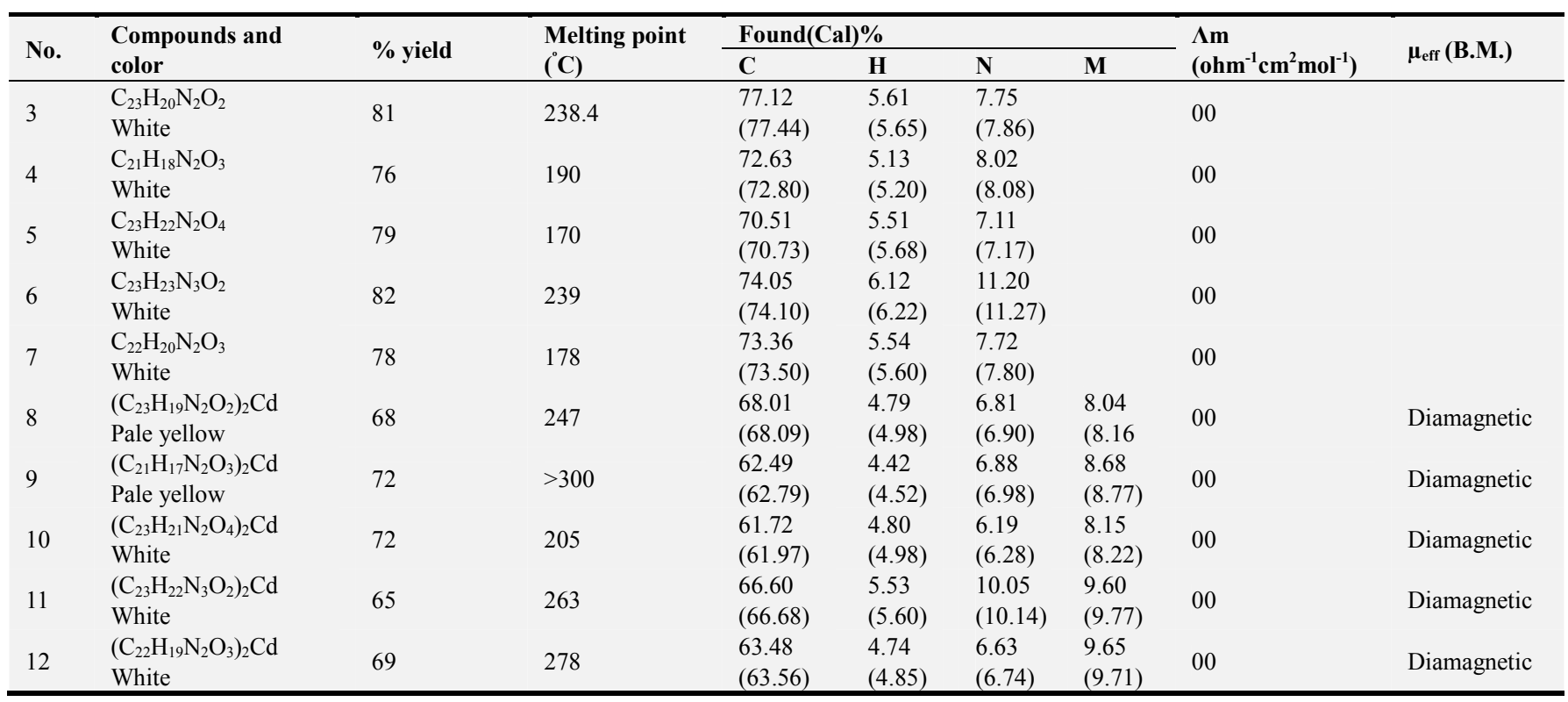




\subsection{Antibacterial Activity}

Antibacterial activities of the ligands and complexes were measured against six pathogenic bacteria. Three of them are gram positive (Bacillus anthracis, Staphylococcus aureus, Bacillus megaterium) other three are gram negative (Shigella flexneri, Escherichia coli, Shigella shiga) bacteria. The reactivity was measured by disc diffusion method. The discs were prepared by using nutrient agar (as a culture media) and the desired amount of ligands or complexes. Then the discs were placed on the freshly seeded (microorganism) agar plates. The plates were kept in a refrigerator for 4 hours in order that the materials get sufficient time to diffuse in a considerable area. After that, the plates were incubated at $37^{\circ} \mathrm{C}$ for 16 hours. After incubation, the diameter of the zone of inhibition was measured in $\mathrm{mm}$. The results were compared with the standard drug, kanamycine.

\section{Results and Discussion}

The reactions of the ligand precursor 4-benzyloxybenzoylhydrazine (2) with different aromatic aldehydes (cinnamaldehyde, 2-hydroxybenzaldehyde, 2,4-dimethoxybenzaldehyde,4-N,N-dimethylaminobenzaldeh yde, 4-methoxybenzaldehyde) formed the ligands (3-7). The ligands react with cadmium acetate formed the complexes (8-12) according to Figure 1. The elemental analyses (Table 1) of the ligands and complexes are consistent with the proposed formula. The conductance values revealed that the complexes were non electrolytic in nature.

The infrared spectral data of the ligands and complexes have been shown in Table 2. The infrared spectra of ethyl-4-benzyloxybenzoate showed a strong absorption peak at $1660 \mathrm{~cm}^{-1}$ for $\mathrm{v}(\mathrm{C}=\mathrm{O})$ stretching. The ligand precursor 2 showed two $v(\mathrm{~N}-\mathrm{H})$ bands at $3292,3190 \mathrm{~cm}^{-1}$ and a $\mathrm{v}(\mathrm{C}=\mathrm{O})$ band at $1640 \mathrm{~cm}^{-1}$ [7]. The ligands (3-7) showed $v(\mathrm{~N}-\mathrm{H})$ at $3178-3286 \mathrm{~cm}^{-1}$ region for the $-\mathrm{C}(\mathrm{O}) \mathrm{NH}-$ moiety. The ligands also showed two absorption peaks at $1635-1713 \mathrm{~cm}^{-1}$ and 1604-1605 $\mathrm{cm}^{-1}$ region for $\mathrm{v}(\mathrm{C}=\mathrm{O})$ and $\mathrm{v}(\mathrm{C}=\mathrm{N})$ bands, respectively which indicated that condensation have been taken place between $-\mathrm{NH}_{2}$ and $-\mathrm{CO}-$ moieties of the ligand precursor and different aldehydes [7, 14]. Infrared spectra of the compounds (8-12) showed a strong band at 1566-1620 $\mathrm{cm}^{-1}$ region for the $v(\mathrm{C}=\mathrm{N}-\mathrm{N}=\mathrm{C})$ moiety. The absence of $\mathrm{v}(\mathrm{N}-$ $\mathrm{H})$ band of the carbohydrazones moiety $(-\mathrm{C}(\mathrm{O}) \mathrm{NH}-\mathrm{N}=\mathrm{C}<$ ) indicated the unequivocal evidence of the formation of chelate complexes $(\mathrm{C}-\mathrm{O}-\mathrm{M})$, via the enol form $[8,15]$. Due to complexation, the $v(\mathrm{C}=\mathrm{N})$ bands were shifted to the lower field. The formation of complexes has also been confirmed by new bands in the IR spectra of the complexes at $470-532 \mathrm{~cm}^{-1}$ and $509-663 \mathrm{~cm}^{-1}$ region, assigned to $v(\mathrm{M}-\mathrm{N})$ and $v(\mathrm{M}-\mathrm{O})$ vibrations, respectively $[1,16]$.

Table 2. Infrared, UV-visible spectral data of the ligands and complexes (1-12).

\begin{tabular}{|c|c|c|c|c|c|c|c|c|}
\hline \multirow[b]{2}{*}{ No. } & \multicolumn{5}{|c|}{ IR in $\mathrm{cm}^{-1}$ (as $\mathrm{KBr}$ disc) } & \multicolumn{3}{|c|}{ UV-visible, $\lambda_{\max }$ in $\mathrm{nm}$} \\
\hline & $v(\mathrm{~N}-\mathrm{H})$ & $v(C=O)$ & $\begin{array}{l}v(C=0) / \\
v(C=0)\end{array}$ & $v(C=0)$ & $v(C=O)$ & $\begin{array}{l}\text { Band I } \\
\pi \rightarrow \pi^{*}\end{array}$ & $\begin{array}{l}\text { BandII } \\
(C=N), n \rightarrow \pi^{*}\end{array}$ & $\begin{array}{l}\text { Band III } \\
(\mathrm{C}=\mathrm{O}), \mathbf{n} \rightarrow \pi^{*}\end{array}$ \\
\hline 1 & & 1660 & & & & & & \\
\hline 2 & 3292,3190 & 1640 & & & & & & \\
\hline 3 & 3240 & 1712 & 1605 & & & 275 & & \\
\hline 4 & 3286 & 1674 & 1605 & & & 280 & 300 & 328 \\
\hline 5 & 3210 & 1713 & 1604 & & & 273 & & 320 \\
\hline 6 & 3186 & 1635 & 1605 & & & 270 & 342 & 374 \\
\hline 7 & 3178 & 1713 & 1605 & & & 275 & 315 & 380 \\
\hline 8 & & & 1598 & 509 & 663 & 295 & 324 & 390 \\
\hline 9 & & & 1574 & 501 & 586 & 305 & 332 & 406 \\
\hline 10 & & & 1566 & 470 & 509,604 & 308 & 328 & 405 \\
\hline 11 & & & 1574,1604 & 516 & 617 & 305 & 365 & 400 \\
\hline 12 & & & 1620,1566 & 532 & 663 & 308 & 375 & 405 \\
\hline
\end{tabular}

The ${ }^{1} \mathrm{H}$ NMR spectral data of the ligands and complexes are shown in the Table 3 . The ${ }^{1} \mathrm{H}$ NMR spectra of the ligand 3 showed a multiplet at $\delta(7.38-7.47)$ for the terminal phenyl protons and a singlet at $\delta 5.14$ for $-\mathrm{CH}_{2} \mathrm{O}-$ protons. The ligand showed two doublets at $\delta 7.95$ and 7.03 for the $\mathrm{H}^{2}{ }^{\prime}, \mathrm{H}^{\prime}$ and $\mathrm{H}-3$ ', 5' protons of aromatic $-\mathrm{C}_{6} \mathrm{H}_{4}-$ moiety, respectively. The ligand showed a singlet at $\delta 8.56$ for the azomethine $(-\mathrm{N}=\mathrm{CH}-)$ proton and a broad singlet at $\delta 7.24$ for the amidic proton of [$\mathrm{C}(=\mathrm{O}) \mathrm{NH}-\mathrm{N}=]$ moiety. The absence of signal for the $-\mathrm{NH}_{2}$ protons in the ligand indicated that Schiff base has been formed by the condensation of $-\mathrm{NH}_{2}$ and $(>\mathrm{C}=\mathrm{O})$ moieties of the hydrazide and aldehyde [3]. The ligand exhibited a triplet at $\delta 7.05$ for the $-\mathrm{CH}=\mathrm{CH}-\mathrm{Ph}$ and a doublet at $\delta 6.75$ for the $\mathrm{CH}=\mathrm{CH}-\mathrm{Ph}$ protons, respectively. The spectra of the complexes showed a singlet at $\delta 7.90$, which has been assigned to the azomethine proton of $[-\mathrm{N}=\mathrm{CHR}]$ moiety. It has been observed that the $\delta$ position of the azomethine moiety ($\mathrm{N}=\mathrm{CH}-$ ) in the complexes has been shifted to the downfield with respect to the free ligand. This might be the result of deshielding effect of azomethine $(-\mathrm{N}=\mathrm{CH}-)$ proton, which confirms the coordination of the $(-\mathrm{N}=\mathrm{CH}-)$ group to the metal centre $\left(\mathrm{Cd}^{2+}\right)$ through the azomethine nitrogen [3, 17]. Moreover, the absence of the ${ }^{1} \mathrm{H}$ NMR signal for amidic proton $[-\mathrm{C}(=\mathrm{O}) \mathrm{NH}-\mathrm{N}=]$ in the complexes indicates that the complexes have been formed by the deprotonation of amidic proton and subsequently coordination via the enolic oxygen atom [1].

The UV-visible spectral data of the ligands and metal 
complexes are shown in Table 2. The ligands (3-7) exhibited absorption maxima in the range of $270-280 \mathrm{~nm}$ which are assigned to $\left(\pi \rightarrow \pi^{*}\right)$ transitions of phenyl rings as well as $(>\mathrm{C}=\mathrm{O})$ and $(-\mathrm{N}=\mathrm{CH}-)$ moieties of the ligand. Moreover, the ligands showed absorption maxima in the range of 300-370 $\mathrm{nm}$ which ascribed to $\left(\mathrm{n} \rightarrow \pi^{*}\right)$ transition for the loan pair of electrons on the hetero atom of $(>\mathrm{C}=\mathrm{O})$ and $(-\mathrm{N}=\mathrm{CH}-)$ moieties. During formation of the complexes, the $\left(\pi \rightarrow \pi^{*}\right)$ transition shifted slightly towards longer wave length, whereas the $\left(n \rightarrow \pi^{*}\right)$ transition of $(>C=O)$ and $(-N=C H-)$ largely shifted to the longer wave lengths, suggesting the chelation of the ligands to the metal center [18]. The complexes did not show any d-d electronic transition due to completely filled $\mathrm{d}^{10}$ electronic configuration of cadmium ion [19]. The complexes exhibited band below $400 \mathrm{~nm}$ assigned to intra ligand charge transfer (ILCT) transition, suggesting the tetrahedral geometry. The complexes are diamagnetic in nature due to completely filled $\mathrm{d}^{10}$ electronic configuration of $\mathrm{Cd}^{2+}$ ion $[1,20]$.

The antibacterial activity of the ligands and complexes were measured against six pathogenic bacteria. Three of them were gram positive (Bacillus anthracis, Staphylococcus aureus, Bacillus megaterium) and other three were gram negative
(Shigella flexneri, Escherichia coli, Shigella shiga) bacteria. The concentrations of the compounds were $20 \mu \mathrm{g} / \mathrm{disc}$. The obtained results were compared with kanamycine as a standard having the same concentration. The results are shown in Table 4. The hydrazone ligands and their metal complexes showed different behavior against the microorganisms. The metal complexes (8-12) had significant antibacterial activity but less as compared to the standard used, while the ligands (3-7) did not show any activity against the organisms. The complexes were found to have higher activity against the gram negative bacteria compared to the gram positive bacteria, which might be due to the different cell membrane structures of the tested microorganisms. Among all the complexes, complex 8 exhibited the least activity, whereas the complex showed the maximum activity against the bacterial strains. The enhanced activities of the complexes can be explained by the chelation theory. It has been reported that the chelation reduces the polarity of the metal ion due to partial sharing of its positive charge with the donor groups of the ligand during complexation [1, 21]. Therefore, the metal ion of the complexes might posses enhanced liphophilic nature which subsequently favors its diffusion through the lipid membrane of the microorganism resulting in higher activity.

Table 3. ${ }^{1} H$ NMR spectral data of the compounds (in ppm) (3-12).

\begin{tabular}{|c|c|}
\hline Compound No. & NMR data \\
\hline 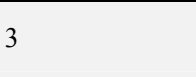 & $\begin{array}{l}\delta: 7.38-7.47\left(\mathrm{~m}, 5 \mathrm{H}, \mathrm{H}-2^{\prime \prime}, 3^{\prime \prime}, 5^{\prime \prime}, 66^{\prime \prime}\right), 5.14\left(\mathrm{~s}, 2 \mathrm{H}, \mathrm{CH}_{2} \mathrm{O}\right), 7.95\left(\mathrm{~d}, 2 \mathrm{H}, \mathrm{H}-2^{\prime}, 6^{\prime}\right), 7.03\left(\mathrm{~d}, 2 \mathrm{H}, \mathrm{H}-33^{\prime}, 5^{\prime}\right), 7.24(\mathrm{~s}, 1 \mathrm{H}, \mathrm{CONH}), 8.56(\mathrm{~s}, 1 \mathrm{H}, \\
\mathrm{N}=\mathrm{CH}), 7.05(\mathrm{t},-\mathrm{CH}=\mathrm{CH}-\mathrm{Ph}), 6.75(\mathrm{~d},-\mathrm{CH}=\mathrm{CH}-\mathrm{Ph})\end{array}$ \\
\hline 4 & $\begin{array}{l}\delta: ~ 7.38-7.47\left(\mathrm{~m}, 5 \mathrm{H}, \mathrm{H}-2^{\prime}, 3^{\prime \prime}, 5^{\prime}, 6^{\prime \prime}\right), 5.14\left(\mathrm{~s}, 2 \mathrm{H}, \mathrm{CH}_{2} \mathrm{O}\right), 7.95\left(\mathrm{~d}, 2 \mathrm{H}, \mathrm{H}-2^{\prime}, 6^{\prime}\right), 7.03(\mathrm{~d}, 2 \mathrm{H}, \mathrm{H}-3 \text { ', 5'), 7.24(s, 1H, CONH), 8.56(s, 1H, } \\
\mathrm{N}=\mathrm{CH}), 7.65\left(\mathrm{~m}, 4 \mathrm{H}, \mathrm{C}_{6} \mathrm{H}_{4}(\mathrm{OH}), 11.71(\mathrm{~s}, 1 \mathrm{H},-\mathrm{OH})\right.\end{array}$ \\
\hline 5 & $\begin{array}{l}\delta: 7.38-7.42\left(\mathrm{~m}, 5 \mathrm{H}, \mathrm{H}-2^{\prime \prime}, 3^{\prime \prime}, 5^{\prime \prime}, 6^{\prime \prime}\right), 5.11\left(\mathrm{~s}, 2 \mathrm{H}, \mathrm{CH}_{2} \mathrm{O}\right), 6.99\left(\mathrm{~d}, 2 \mathrm{H}, \mathrm{H}-2^{\prime}, 6^{\prime}\right), 7.03(\mathrm{~d}, 2 \mathrm{H}, \mathrm{H}-3 \text { ', 5'), 7.25(s, 1H, CONH), 7.44((s,1H, } \\
\mathrm{N}=\mathrm{CH}), 3.87\left(\mathrm{~s}, 2 \times 3 \mathrm{H}, \mathrm{OCH}_{3}\right), 7.34(\mathrm{~m}, 3 \mathrm{H}, \mathrm{H}-3,5,6)\end{array}$ \\
\hline 6 & $\begin{array}{l}\delta: 7.38-7.47\left(\mathrm{~m}, 5 \mathrm{H}, \mathrm{H}-2^{\prime}, 3^{\prime \prime}, 5 ”, 6 ”\right), 5.14\left(\mathrm{~s}, 2 \mathrm{H}, \mathrm{CH}_{2} \mathrm{O}\right), 7.95(\mathrm{~d}, 2 \mathrm{H}, \mathrm{H}-2 \text { ', 6'), 7.03(d, 2H, H-3',5'), 7.24(s, 1H, CONH), 8.56(s, 1H, } \\
\mathrm{N}=\mathrm{CH}), 6.70(\mathrm{~d}, 2 \mathrm{H}, \mathrm{H}-2,6,), 7.58(\mathrm{~d}, 2 \mathrm{H}, \mathrm{H}-3,5), 3.34\left(\mathrm{~s}, 6 \mathrm{H}, \mathrm{N}\left(\mathrm{CH}_{3}\right)_{2}\right)\end{array}$ \\
\hline 7 & $\begin{array}{l}\delta: ~ 7.33-7.45\left(\mathrm{~m}, 5 \mathrm{H}, \mathrm{H}-2^{\prime}, 3^{\prime \prime}, 5^{\prime}, 6^{\prime \prime}\right), 5.12\left(\mathrm{~s}, 2 \mathrm{H}, \mathrm{CH}_{2} \mathrm{O}\right), 7.35\left(\mathrm{~d}, 2 \mathrm{H}, \mathrm{H}-2^{\prime}, 6^{\prime}\right), 7.90-7.03\left(\mathrm{~d}, 2 \mathrm{H}, \mathrm{H}-3^{\prime}, 5^{\prime}\right), 8.35(\mathrm{~s}, 1 \mathrm{H}, \mathrm{C}=\mathrm{NH}), 7.92(\mathrm{~s}, \\
1 \mathrm{H}, \mathrm{CONH}), 7.71(\mathrm{~d}, 2 \mathrm{H}, \mathrm{H}-2,6), 6.95(\mathrm{~d}, 2 \mathrm{H}, \mathrm{H}-3,5), 3.85\left(\mathrm{~s}, 3 \mathrm{H}, \mathrm{OCH}_{3}\right)\end{array}$ \\
\hline 8 & 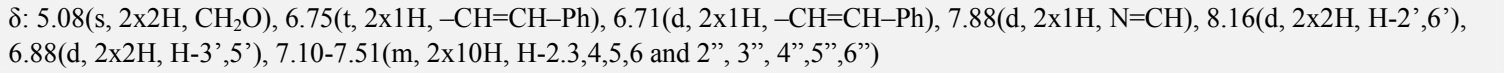 \\
\hline 9 & $\begin{array}{l}\delta: 5.16\left(\mathrm{~s}, 2 \times 2 \mathrm{H}, \mathrm{CH}_{2} \mathrm{O}\right), 7.30-7.50\left(\mathrm{~m}, 2 \times 10 \mathrm{H}, \mathrm{H}-2^{\prime \prime}, 3^{\prime \prime}, 4^{\prime \prime}, 5^{\prime \prime}, 6^{\prime \prime} \text { and } \mathrm{H}-3,4,5,6\right), 8.27(\mathrm{~s}, 2 \times 1 \mathrm{H}, \mathrm{N}=\mathrm{CH}), 8.16\left(\mathrm{~d}, 2 \times 2 \mathrm{H}, \mathrm{H}-2^{\prime}, 6^{\prime}\right) \\
6.88\left(\mathrm{~d}, 2 \times 2 \mathrm{H}, \mathrm{H}-3^{\prime}, 5^{\prime}\right), 8.54(\mathrm{~s}, 2 \times 1 \mathrm{H},-\mathrm{OH})\end{array}$ \\
\hline 10 & $\begin{array}{l}\delta: 5.12\left(\mathrm{~s}, 2 \times 2 \mathrm{H}, \mathrm{CH}_{2} \mathrm{O}\right), 7.33-7.68\left(\mathrm{~m}, 2 \times 5 \mathrm{H}, \mathrm{H}-2 ”, 3 ”, 4^{\prime \prime}, 5 ”, 6 ”\right), 7.02(\mathrm{~d}, 2 \times 2 \mathrm{H}, \mathrm{H}-3 \text { ', 5'), 7.06(d, 2x2H, H-2', 6’), 7.68(s, 2x1H, } \\
\mathrm{N}=\mathrm{CH}), 6.51(\mathrm{~d}, 2 \times 1 \mathrm{H}, \mathrm{H}-6), 6.58(\mathrm{~d}, 2 \times 1 \mathrm{H}, \mathrm{H}-5), 6.65(\mathrm{~s}, 2 \times 1 \mathrm{H}, \mathrm{H}-3), 3.84\left(\mathrm{~s}, 2 \times 6 \mathrm{H}, \mathrm{OCH}_{3}\right)\end{array}$ \\
\hline 11 & $\begin{array}{l}\delta: 5.17\left(\mathrm{~s}, 2 \times 2 \mathrm{H}, \mathrm{CH}_{2} \mathrm{O}\right), 7.45-7.66\left(\mathrm{~m}, 2 \times 5 \mathrm{H}, \mathrm{H}-2 ”, 3 ”, 4^{\prime \prime}, 5^{\prime \prime}, 6^{\prime \prime}\right), 7.02(\mathrm{~d}, 2 \times 2 \mathrm{H}, \mathrm{H}-3 \text { ', 5'), 7.06(d, 2x2H, H-2', 6’), 7.72(s, 2x1H, } \\
\mathrm{N}=\mathrm{CH}), 7.36(\mathrm{~d}, 2 \times 2 \mathrm{H}, \mathrm{H}-2,6), 6.68(\mathrm{~d}, 2 \times 2 \mathrm{H}, \mathrm{H}-3,5), 3.02\left(\mathrm{~s}, 2 \times 6 \mathrm{H}, \mathrm{N}\left(\mathrm{CH}_{3}\right)_{2}\right)\end{array}$ \\
\hline 12 & $\begin{array}{l}\delta: 5.17\left(\mathrm{~s}, 2 \times 2 \mathrm{H}, \mathrm{CH}_{2} \mathrm{O}\right), 7.45-7.66\left(\mathrm{~m}, 2 \times 5 \mathrm{H}, \mathrm{H}-2 ”, 3^{\prime}, 4^{\prime \prime}, 5^{\prime \prime}, 6^{\prime \prime}\right), 7.02(\mathrm{~d}, 2 \times 2 \mathrm{H}, \mathrm{H}-3 \text { ', 5'), 7.06(d, 2x2H, H-2', 6'), 7.72(s, 2x1H, } \\
\mathrm{N}=\mathrm{CH}), 7.36(\mathrm{~d}, 2 \times 2 \mathrm{H}, \mathrm{H}-2,6), 6.68(\mathrm{~d}, 2 \times 2 \mathrm{H}, \mathrm{H}-3,5), 3.81\left(\mathrm{~s}, 2 \times 3 \mathrm{H}, \mathrm{OCH}_{3}\right)\end{array}$ \\
\hline
\end{tabular}

\section{Conclusion}

The Schiff base ligands [N-aroylidene(4-benzyloxy benzoylhydrazone)], $\mathrm{C}_{6} \mathrm{H}_{5} \mathrm{CH}_{2} \mathrm{OC}_{6} \mathrm{H}_{4} \mathrm{CONHN}=\mathrm{CHR}$ have been formed successfully by the condensation reaction of 4-benzyloxybenzoylhydrazine, $\mathrm{C}_{6} \mathrm{H}_{5} \mathrm{CH}_{2} \mathrm{OC}_{6} \mathrm{H}_{4} \mathrm{CONHNH}_{2}$ with different aromatic aldehydes in ethanol. The Schiff base ligands were used to synthesize corresponding bis[N-aroylidene(4-benzyloxybenzoylhydrazinato)]Cd(II) complexes having the general formula $\left[\mathrm{C}_{6} \mathrm{H}_{5} \mathrm{CH}_{2} \mathrm{OC}_{6} \mathrm{H}_{4} \mathrm{CONHN}=\mathrm{CHR}\right]_{2} \mathrm{Cd}(\mathrm{II})$. The IR, ${ }^{1} \mathrm{H}$ NMR spectroscopic results suggested that the complexes were formed in a 2:1 ligand to metal molar ratio and the ligands coordinated with the metal ion in uninegative bidentate mode via the deprotonation through the enol form. The conductivity measurement data revealed that the complexes are non-electrolytic in nature. The UV-visible data of the complexes suggested the tetrahedral geometry of $\mathrm{Cd}(\mathrm{II})$ ion. The antibacterial activity test showed that the ligands exhibited very low or no activity, while their corresponding complexes demonstrated activity against the bacterial strains. The result concluded that the activity showed by the complexes is solely due to the presence of Cadmium(II) ion. Therefore, it can be said that the metal ion of complexes plays an important role in increasing the biological activity of organic ligands. 
Table 4. Antibacterial activity data of the ligands and complexes (3-12).

\begin{tabular}{|c|c|c|c|c|c|c|c|}
\hline \multirow[b]{2}{*}{$\begin{array}{l}\text { Compounds } \\
\text { Name/Standard }\end{array}$} & \multirow[b]{2}{*}{ No. } & \multicolumn{6}{|c|}{ Zone of inhibition (mm) against bacteria } \\
\hline & & $\begin{array}{l}\text { Bacillus } \\
\text { anthracis, (gram } \\
\text { positive) }\end{array}$ & $\begin{array}{l}\text { Staphylococcus } \\
\text { aureus, (gram } \\
\text { positive) }\end{array}$ & $\begin{array}{l}\text { Bacillus } \\
\text { megaterium,(gra } \\
\text { m positive) } \\
\end{array}$ & $\begin{array}{l}\text { Shigella } \\
\text { flexneri,(gram } \\
\text { negative) }\end{array}$ & $\begin{array}{l}\text { Escherichia coli, } \\
\text { (gram negative) }\end{array}$ & $\begin{array}{l}\text { Shigella } \\
\text { shiga,(gram } \\
\text { negative) } \\
\end{array}$ \\
\hline \multirow{5}{*}{ Ligands } & 3 & - & - & - & - & - & - \\
\hline & 4 & - & - & - & - & - & - \\
\hline & 5 & & - & - & - & - & - \\
\hline & 6 & - & - & - & - & - & - \\
\hline & 7 & - & - & - & - & - & - \\
\hline \multirow{5}{*}{ Complexes } & 8 & 6 & 7 & 8 & 3 & 2 & 4 \\
\hline & 9 & 3 & 1 & 7 & 14 & 8 & 10 \\
\hline & 10 & 8 & 9 & 10 & 15 & 12 & 11 \\
\hline & 11 & 7 & 8 & 12 & 12 & 11 & 12 \\
\hline & 12 & 7 & 6 & 9 & 9 & 9 & 10 \\
\hline Kanamycine & Drug & 25 & 28 & 30 & 25 & 25 & 25 \\
\hline
\end{tabular}

\section{Acknowledgements}

The authors would like to thanks Department of Chemistry, Rajshahi University, Bangladesh for providing necessary chemicals and laboratory facilities. The authors are also grateful to Md. Chanmiya Sheikh, Department of Applied Chemistry, Toyama University, Japan for his assistance to provide the ${ }^{1} \mathrm{H}$ NMR.

\section{References}

[1] Bhaskar R., Salunkhe N., Yaul A., Aswar A. (2015) Bivalent transition metal complexes of ONO donor hydrazone ligand: synthesis, structural characterization and antimicrobial activity. Spectrochimica Acta Part A, 151: 621-627.

[2] Li Y., Yang Z., Zhou M., He J., Wang X., Wu Y., Wang Z. (2017) Syntheses, crystal structures and DNA-binding studies of $\mathrm{Cu}$ (II) and $\mathrm{Zn}$ (II) complexes bearing asymmetrical aroylhydrazone ligand. Journal of Molecular Structure, 1130: 818-828.

[3] Howlader M. B., Islam M. S. (2007) Synthesis of some Ni (II) complexes containing 4-substituted benzylidene (4-benzyloxy) benzoylhydrazone ligand. Indian Journal of Chemistry, 46A: 440-444.

[4] Hosseini-Monfared H., Pousaneh E, Sadighian S., Ng S. W., Tiekink E. R. (2013) Syntheses, Structures, and Catalytic Activity of Copper (II)-Aroylhydrazone Complexes. Zeitschrift für anorganische und allgemeine Chemie, 639 (2): 435-442.

[5] Monfared H. H., Sadighian S., Kamyabi M. A., Mayer P. (2009) Iron (III) aroylhydrazone complexes: Structure, electrochemical studies and catalytic activity in oxidation of olefins. Journal of Molecular Catalysis A, 304 (1-2): 139-146.

[6] Mathews N. A., Jose A., Kurup M. P. (2019) Synthesis and characterization of a new aroylhydrazone ligand and its cobalt (III) complexes: X-ray crystallography and in vitro evaluation of antibacterial and antifungal activities. Journal of Molecular Structure, 1178: 544-553.

[7] Singh V. P., Singh S., Singh D. P., Singh P., Tiwari K., Mishra M., Butcher R. J. (2013) Synthesis, spectral and single crystal $\mathrm{X}$-ray diffraction studies on Co (II), Ni (II), Cu (II) and Zn (II) complexes with o-amino acetophenone benzoyl hydrazone. Polyhedron, 56: 71-81.

[8] Singh S. K., Singh H. K., Nandi R., Kumar V., Tarcea N., Popp J., Singh R. K., Singh B. (2014) Synthesis, characterization and mesomorphic investigations of ester-substituted aroylhydrazones possessing a lateral hydroxyl group. Polyhedron, 74: 99-112.

[9] Singh S. K., Kumar V., Singh H. K., Kanth P., Singh B. (2015) Microwave-assisted synthesis, characterisation and mesomorphic investigations of novel disubstituted aroylhydrazones. Liquid Crystals, 42 (8): 1179-1190.

[10] Akinyele O. F., Akinnusi T. O., Ajayeoba T. A., Ayeni A. O., Durosinmi L. M., (2019) Synthesis, Characterization and Antimicrobial Activities of Cobalt (II), Nickel (II) and Copper (II) Complexes of Aroylhydrazone Mixed with Aspirin. Science Journal of Chemistry, 7 (3): 67-71.

[11] Sutradhar M., Roy Barman T., Pombeiro A. J., Martins L. M. (2019) Ni (II)-Aroylhydrazone Complexes as Catalyst Precursors Towards Efficient Solvent-Free Nitroaldol Condensation Reaction. Catalysts, 9 (6): 554.

[12] Aboafia S. A., Elsayed S. A., El-Sayed A. K., El-Hendawy A. M. (2018) New transition metal complexes of 2, 4-dihydroxybenzaldehyde benzoylhydrazone Schiff base (H2dhbh): synthesis, spectroscopic characterization, DNA binding/cleavage and antioxidant activity. Journal of Molecular Structure, 1158: 39-50.

[13] Walter J. L., Freiser H. (1952) 2-(o-Hydroxyphenyl)-Benzoxazole as Reagent for Gravimetric Determination of Cadmium. Analytical Chemistry, 24 (6): 984-996.

[14] Singh V. P. (2008) Synthesis, electronic and ESR spectral studies on copper (II) nitrate complexes with some acylhydrazines and hydrazones. Spectrochimica Acta Part A, 71 (1): 17-22.

[15] Iskander M. F., El-Aggan A. M., Refaat L. S., El Sayed L. (1975) Coordination compounds of hydrazine derivatives with transition metals. VIII. Copper (II) complexes with salicylaldehyde and acetylacetone aroyl-hydrazones. Inorganica Chimica Acta, 14: 167-172.

[16] Harinath Y., Reddy D. H., Kumar B. N., Apparao C., Seshaiah K. (2013) Synthesis, spectral characterization and antioxidant activity studies of a bidentate Schiff base, 5-methyl thiophene-2-carboxaldehyde-carbohydrazone and its Cd (II), $\mathrm{Cu}$ (II), Ni (II) and Zn (II) complexes. Spectrochimica Acta Part A, 101: 264-272. 
[17] Justin D. C., Sivasankaran N. M. (2009) Synthesis, characterization, and antimicrobial studies of some Schiff-base metal (II) complexes. Journal of Coordination Chemistry, 62 (24): 4018-4028.

[18] Chakrabarty M., Ahmed A., Lal R. A. (2015) Synthesis, characterization, and structural assessment of $\mathrm{Ni}$ (II) complexes derived from bis (2-hydroxy-1-naphthaldehyde) succinoyldihydrazone. International Journal of Inorganic Chemistry, Article ID 121895.

[19] Montazerozohori M., Zahedi S., Nasr-Esfahani M., Naghiha A. (2014) Some new cadmium complexes: antibacterial/antifungal activity and thermal behavior. Journal of Industrial and Engineering Chemistry, 20 (4): 2463-2470.

[20] Montazerozohori M., Joohari S., Musavi S. A. (2009) Synthesis and spectroscopic studies of some cadmium (II) and mercury (II) complexes of an asymmetrical bidentate Schiff base ligand. Spectrochimica Acta Part A, 73 (2): 231-237.

[21] Prakash A., Singh B. K., Bhojak N., Adhikari D. (2010) Synthesis and characterization of bioactive zinc (II) and cadmium (II) complexes with new Schiff bases derived from 4-nitrobenzaldehyde and acetophenone with ethylenediamine. Spectrochimica Acta PartA, 76 (3-4): 356-362. 